\title{
Phenylalanine ammonia lyase (PAL) activity in genotypes of Opuntia spp. against artificial infestation of Dactylopius opuntiae submitted to biotic and abiotic resistance
}

\section{inducers}

\author{
Atividade da fenilalanina amônia-liase (FAL) em genótipos de Opuntia spp. frente a infestação \\ artificial de Dactylopius opuntiae submetidas a indutores de resistência bióticos e abióticos
}

Actividad de fenilalanina amoniaco liasa (FAL) en Opuntia spp. contra la infestación artificial de Dactylopius opuntiae sometida a inductores de resistencia biótica y abiótica

\begin{abstract}
Products of biotic and abiotic origin are being investigated for use in pest management, many of these substances can act as resistance inducers, which induces the metabolism of enzymes involved in defense mechanisms. There is a search for efficient and alternative ways of controlling carmine cochineal (Dactylopius opuntiae Cockerell), the main pest of forage palm (Opuntia spp) in Northeast Brazil. The aim of the study was to evaluate the application of biotic and abiotic inducers on the palms to induce resistance through the activity of the antioxidant enzyme phenylalanine ammonia lyase. The experiment was carried out in a greenhouse at the Federal University of Agreste of Pernambuco, using an Completely Randomized Design (CRD), distributed in a factorial scheme $(3 \times 8 \times 3)$ with three Opuntia genotypes, eight treatments: Trichoderma viride URM 6824, Trichoderma viride URM 6823, Aureobasidium pullulans URM 6874, salicylic acid, chitosan, amino butyric acid, distilled water with the insect (positive control), distilled water without the insect (negative control), with three collection periods and four repetitions. The results
\end{abstract}


were subjected to analysis of variance (ANOVA), the means being compared by the Scott-Knott test at the level of $5 \%$ probability $(\mathrm{p}<0.05)$ and by orthogonal contrasts. The biological inducers $T$. viride URM 6824 and T. viride URM 6823 as well amino butyric acid influenced the increase in the enzymatic activity of phenylalanine ammonia lyase. This result demonstrates the potential for use in alternative management, and future studies are needed to deepen the applicability in field conditions.

Keywords: Carmine cochineal; Oxidative enzymes; Infestation; Forage palm.

\title{
Resumo
}

Produtos de origem biótica e abiótica estão sendo investigados para utilização no manejo de pragas, muitas destas substâncias podem atuar como indutores de resistência, o que induz a metabolização de enzimas envolvidas nos mecanismos de defesa. Há uma busca por formas eficientes e alternativas de controle da cochonilha do carmim (Dactylopius opuntiae Cockerell) principal praga da palma forrageira (Opuntia spp) no Nordeste do Brasil. O objetivo do estudo foi avaliar a aplicação de indutores bióticos e abióticos em palmas na indução de resistência através da atividade da enzima antioxidante fenilalanina amônia liase. O experimento foi conduzido em casa de vegetação na Universidade Federal do Agreste de Pernambuco, utilizando-se um Delineamento Inteiramente Casualizado (DIC), distribuído em esquema fatorial $(3 \times 8 \times 3)$ sendo três genótipos de Opuntia, oito tratamentos: Trichoderma viride URM 6824, Trichoderma viride URM 6823, Aureobasidium pullulans URM 6874, ácido salicílico, quitosana, ácido amino butírico (BABA), água destilada com o inseto (controle positivo), água destilada sem o inseto (controle negativo), com três períodos de coleta e quatro repetições. Os resultados foram submetidos a análise de variância (ANOVA), sendo as médias comparadas pelo teste de Scott-Knott ao nível de 5\% de probabilidade $(\mathrm{p}<0,05)$ e por contrastes ortogonais. Os indutores biológicos T. viride URM 6824 e $T$. viride URM 6823 assim como o BABA influenciaram no aumento da atividade enzimática da fenilalanina amônia liase. Resultado demonstra a potencialidade de utilização no manejo alternativo, cabendo estudos futuros para aprofundamento sobre aplicabilidade em condições de campo.

Palavras-chave: Cochonilha do carmim; Enzimas oxidativas; Infestação; Palma forrageira.

\begin{abstract}
Resumen
Se están investigando productos de origen biótico y abiótico para su uso en el manejo de plagas, muchas de estas sustancias pueden actuar como inductores de resistencia, lo que induce el metabolismo de enzimas involucradas en los mecanismos de defensa. Se buscan formas eficientes y alternativas de control de la cochinilla carmín (Dactylopius opuntiae Cockerell), principal plaga de la palma forrajera (Opuntia spp) en el noreste de Brasil. El objetivo del estudio fue evaluar la aplicación de inductores bióticos y abióticos en las palmas para inducir resistencia a través de la actividad de la enzima antioxidante fenilalanina amoniaco liasa (FAL). El experimento se llevó a cabo en un invernadero de la Universidad Federal de Agreste de Pernambuco, utilizando un Diseño Completamente Aleatorio (DCA), distribuido en un esquema factorial (3x8x3) con tres genotipos de Opuntia, ocho tratamientos: Trichoderma viride URM 6824, Trichoderma viride URM 6823, Aureobasidium pullulans URM 6874, ácido salicílico, quitosano, ácido amino butírico, agua destilada con el insecto (control positivo), agua destilada sin el insecto (control negativo), con tres períodos de recolección y cuatro repeticiones. Los resultados se sometieron a análisis de varianza (ANOVA), comparándose las medias mediante la prueba de Scott-Knott al nivel de $5 \%$ de probabilidad $(\mathrm{p}<0,05)$ y mediante contrastes ortogonales. Los inductores biológicos T. viride URM 6824 y T. viride URM 6823 así como ácido amino butírico influyeron en el aumento de la actividad enzimática de FAL. Este resultado demuestra el potencial de uso en manejo alternativo, y se necesitan estudios futuros para profundizar la aplicabilidad en condiciones de campo.
\end{abstract}

Palabras clave: Cochinilla carmín; Enzimas oxidativas; Infestación; Palma forrajera.

\section{Introduction}

In the Northeast of Brazil, agriculture and livestock activities are strongly marked by the negative rainfall indexes resulting from high temperatures with annual averages of $28{ }^{\circ} \mathrm{C}$ and sunshine of $2800 \mathrm{~h}$ year ${ }^{-1}$ and rainy season that is concentrated on average three months of the year, being the annual rainfall equal to or less than $800 \mathrm{~mm}$ (Sousa, 2019).

In this scenery, livestock stands out as an economic activity that directly impacts the gross income of families in which the rural environment is responsible for the main source of income, as highlighted by the study by Dubeux Jr et al. (2015) when affirming that this activity presents greater resilience to drought compared to agriculture, thus having a characteristic that contributes to the permanence of man in the countryside, minimizing the rural exodus. The cultivation of forage palm stands out for being a food source for animals, as it presents a high biomass production per unit area, ensuring that the nutritional demand of the herds is met and presents a low risk in view of climatic uncertainties (Carvalho et al., 2018). 
This crop acts as a forage reserve, characterized by being rich in energy and water, which significantly contributes to the sustainability of dairy farming, especially in the states of Pernambuco, Paraíba, Alagoas and Sergipe (Peixoto et al., 2018). Guarantee benefits are available when agronomic practices are carried out correctly, from the choice of the cultivation system, the cultural treatments used, the intensity and frequency that the harvests took place, as well as the control of phytosanitary aspects, mainly pests.

The crop is affected throughout its cycle by several pests with the potential to cause damage capable of partially and even totally jeopardizing the production of plant biomass. Currently, phytosanitary aspects are among the main factors limiting forage exploitation (Ferraz et al., 2017). One of the main pests of the forage palm is the carmine cochineal (Dactylopius opuntiae), which by means of suction mechanisms, these insects inject toxic saliva into the plants, causing yellowing (chlorosis), decay, tipping and death. Luna et al. (2018) stated that an infestation greater than $75 \%$ leads to death of the plant. An alternative to combat is the use of agents that make the plant resistant to this insect pest.

In modern agriculture there is the possibility of inducing resistance and numerous researches have already proven efficiency in several plants of agricultural importance for Brazil. Induction occurs through the application of elicitors that can be of biotic origin (viable or inactivated microorganisms) and abiotic (Pascholati et al., 2019). Can be applied in the area and in the soil, close to the root absorption system (Melo et al., 2016).

Inductors can also be called plant fortifiers and have the ability to protect against attack by pests and pathogens, which impacts on crop yields. Most work by modifying plant defence signalling pathways, but little is known about how chain reactions occur in signalling activation (Wang et al., 2020). One of the ways to verify the action of these inducers on plants is to verify the activity of some enzymes of oxidative stress, an example is phenylalanine ammonia lyase, which in certain amounts determine positive rates in the resistance of plants to attacks (Almeida et al., 2012). Resistance inducers act in defence and their responses can be elucidated through phenylalanine ammonia-lyase (Silva et al., 2018).

The research presents and evaluates the application of resistance inducers in cladodes of palms of the varieties F8, IPA 200008, Opuntia atropes, Rose; IPA clone 20, IPA 100003 O. ficus indica and IPA 200016, O. stricta (Haw.) Haw against artificial infestation by $D$. opuntiae, quantifying the activity of the enzyme phenylalanine ammonia lyase and its association with plant resistance to biotic stress.

\section{Methodology}

The experiment was carried out under controlled conditions, in a greenhouse at the Federal University of Agreste de Pernambuco - UFAPE, in the municipality of Garanhuns located in the southern Agreste region of the state of Pernambuco in Brazil, under the geographic coordinates: $08^{\circ} 53^{\prime} 25^{\prime \prime}$ latitude south and $36^{\circ} 29^{\prime} 34^{\prime \prime}$ west longitude, with an average altitude of 896m (Canuto et al., 2019). The experimental period was from August 13, 2019 to March 26, 2020, lasting 226 days, under averages temperature of $23.11^{\circ} \mathrm{C}$ and humidity of $80.54 \%$ (INMET, 2020).

As biotic inducers, fungi from the URM Micoteca Cultures collection of the Mycology Department of the Biosciences Center of the Federal University of Pernambuco were used, isolated from Cereus jamacaru DC. (Mandacaru, Cactaceae): Trichoderma viride URM 6824, Trichoderma viride URM 6823 and Aureobasidium pullulans URM 6874. They were grown in a Potato-Dextrose-Agar (PDA) culture medium and the $28{ }^{\circ} \mathrm{C}$ growth occurred in a BOD incubator for 15 days at the Microbiology, Enzyme Technology and Bioproducts Laboratory at UFAPE, a spore suspension in the concentration of 106 was applied to the plants and abiotic inducers were used, salicylic acid $(2 \mathrm{mM})$, chitosan $\left(4 \mathrm{mg} \mathrm{mL}^{-1}\right)$ and DL- $\beta$-amino-nbutyric $(3 \mathrm{mM})$. 
The plants of cultivars F8, IPA 200008, Opuntia atropes, Rose; IPA clone 20 (Tolerant), IPA 100003 O. ficus indica (Susceptible) and IPA 200016, O. stricta (Haw.) Haw (Resistant) were grown in pots with a capacity of 20L filled with soil classified as sandy, which presented the following contents for clay, silt and sand respectively: $60.0 \mathrm{~g} \mathrm{~kg}^{-1}, 20.0 \mathrm{~g} \mathrm{~kg}^{-1}$ and $920.0 \mathrm{~g} \mathrm{~kg}^{-1}$ and with $23.0 \mathrm{~g} \mathrm{~kg}^{-1}$ of total organic matter (Table 1).

Table 1. Chemical analysis of the soil used in the experiment, collected at a depth of $0-20 \mathrm{~cm}$.

\begin{tabular}{cccccccccc|cccccc}
\hline $\mathrm{pH}$ & \multicolumn{9}{c}{$\mathrm{mg} \mathrm{dm}^{3}$} & \multicolumn{4}{c}{$\mathrm{cmol}_{\mathrm{c}} \mathrm{dm}^{3}$} & \multicolumn{4}{c}{$(\mathrm{V} \%)$} \\
$\left(\mathrm{H}_{2} \mathrm{O}\right)$ & $\mathrm{K}$ & $\mathrm{Na}$ & $\mathrm{S}$ & $\mathrm{B}$ & $\mathrm{Cu}$ & $\mathrm{Fe}$ & $\mathrm{Mn}$ & $\mathrm{P}$ & $\mathrm{Zn}$ & $\mathrm{Ca}$ & $\mathrm{Mg}$ & $\mathrm{Al}$ & $\mathrm{H}+\mathrm{Al}$ & $\mathrm{CTC}$ & $\mathrm{SB}$ \\
\hline 6.20 & 78 & 1.0 & 5 & 0.25 & 0.9 & 6.7 & 23 & 36 & 1 & 1.9 & 0.5 & 0.0 & 3.4 & 6.00 & 43 \\
\hline
\end{tabular}

Source: Authors.

The propagation materials (cladodes) were obtained from the germplasm bank in vivo of the Agronomic Institute of Pernambuco-IPA, located in the municipality of Arcoverde-PE. After harvesting, they were sanitized with $2 \%$ sodium hypochlorite solution and $20 \%$ neutral detergent, then they were stored for 19 days in a dry place, and protected from direct solar radiation, for the healing of the cut. After 60 days of planting, a uniform thinning was carried out, leaving only the primary cladodes in each plant, and at 136 days of planting, the cladodes were sprayed to the point of runoff with the solutions of the resistance inducers that were also applied via $40 \mathrm{~mL}$ soil, and the controls were sprayed with distilled water only.

Ten days after induction, the plants were artificially infested with $D$. opuntiae specimens, except for negative controls. The insects came from the IPA and kept in breeding at the applied entomology sector at the Laboratory Support Center for Research at UFAPE. The infestation occurred by fixing fragments of cladodes with dimensions of $8 \times 5 \pm 2 \mathrm{~cm}$ containing 50 colonies of the insect in the laying stage in which the plants were fixed with cords.

Three collections of plant material were performed to analysed the PAL activity, which occurred on the $15^{\text {th }}, 45^{\text {th }}$ and $75^{\text {th }}$ days after the artificial infestation by $D$. opuntiae. One gram of fresh tissue was incised in the central part of the top cladode with a sterile scalpel and, later macerated in liquid $\mathrm{N}_{2}$ in a mortar, the samples initially acquired a brittle appearance and soon after the composition of the cladodes, a pasty consistency appeared, then it was homogenized in a buffer solution with the addition of polyvinylpyrrolidone (PVP) $50 \mathrm{mg}(\mathrm{w} / \mathrm{v})$ and subsequently centrifuged (10,000 rpm) at $4{ }^{\circ} \mathrm{C}$. Such activity was determined according to Zucker (1968), in which the reaction is initiated after the addition of the plant extract obtained by macerating $1 \mathrm{~g}$ of cladodium, to a mixture containing $25 \mathrm{mM}$ Tris- $\mathrm{HCl}$ buffer (pH 8.8 ) and $100 \mathrm{mM} \mathrm{L-}$ phenylalanine. The reaction mixture was incubated in a water bath at $30{ }^{\circ} \mathrm{C}$ for 2 hours. In the control samples, Lphenylalanine was replaced by Tris- $\mathrm{HCl}$ buffer. The reaction was terminated after adding $6 \mathrm{~N} \mathrm{HCl}$. The absorbance of transcinnamic acid derivatives as a reaction product of the enzymatic reaction was measured in a spectrophotometer at $290 \mathrm{~nm}$ and

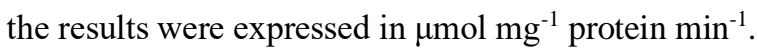

The experimental design used was completely randomized, with a 3x8x3 factorial scheme ( 3 palm genotypes, 8 resistance inducers and 3 collection periods). The data were evaluated by analysis of variance (ANOVA), using the statistical program SISVAR (version 5.6) and the means compared by the Scott-Knott test, adopting a significance level of 5\%, orthogonal contrasts were also performed.

\section{Results and Discussion}

Throughout cultivation, plants are exposed to numerous biotic and / or abiotic factors that can negatively affect their metabolism and, consequently, production. Thus, research on the use of new resistance inducers has been developed in order to 
evaluate them as an alternative to traditional management. The activity of some enzymes of oxidative stress such as phenylalanine ammonia lyase, are considered markers of efficiency in the use of inductors (Almeida et al., 2012; Silva et al., 2018).

Orthogonal contrasts were performed to understand how the set of biotic and abiotic inducers influenced the PAL activity, for this the treatments and the controls (negative and positive), analysed statistically and the results are shown in Table 2. For contrasts between the averages of activity of biological treatments versus positive control and the results were significant for the three varieties.

Table 2. Orthogonal contrast of the activity of phenylalanine ammonia lyase $\left(\mu \mathrm{mol} \mathrm{mg} \mathrm{mprot}^{-1} \mathrm{~min}^{-1}\right)$ in three genotypes of palms, artificially infested with $D$. opuntiae, after application of biotic resistance inducers (T. viride URM 6824, T. viride URM 6823 and A. pullulans URM 6874) and abiotics (chitosan, salicylic acid and aminobutyric acid).

\begin{tabular}{|c|c|c|c|}
\hline Treatment & Tolerant Genotype & Susceptible Genotype & Resistant Genotype \\
\hline Chemicals & 8.728 & 11.846 & 9.192 \\
\hline Biological & 9.986 & 12.485 & 11.965 \\
\hline Positive & 6.952 & 7.752 & 6.994 \\
\hline Negative & 11.897 & 11.352 & 14.551 \\
\hline Overall average & 9.374 & 11.512 & 10.627 \\
\hline \multicolumn{4}{|c|}{ Biological treatments vs. Positive control } \\
\hline Test $\mathrm{t}$ & $3.663 *$ & $2.565^{*}$ & $5.238 *$ \\
\hline $\mathrm{CV}(\%)$ & 26.48 & 28.08 & 26.79 \\
\hline \multicolumn{4}{|c|}{ Chemical treatments vs. Positive control } \\
\hline Test $\mathrm{t}$ & $2.142 *$ & $2.219^{*}$ & $2.316^{*}$ \\
\hline $\mathrm{CV}(\%)$ & 23.63 & 25.32 & 23.68 \\
\hline \multicolumn{4}{|c|}{ Biological treatments vs. Negative control } \\
\hline Test t & $-2.310^{*}$ & $0.614^{\mathrm{ns}}$ & $-2.725^{*}$ \\
\hline $\mathrm{CV}(\%)$ & 24.75 & 25.49 & 23.56 \\
\hline \multicolumn{4}{|c|}{ Chemical treatments $v s$. Negative control } \\
\hline Test $\mathrm{t}$ & $-3.831 *$ & $0.268^{\mathrm{ns}}$ & $-5.648 *$ \\
\hline $\mathrm{CV}(\%)$ & 22.93 & 26.65 & 24.89 \\
\hline
\end{tabular}

${ }^{\mathrm{ns}}$ Not significant; * significant at 5\% probability by t test; CV Coefficient of variation; Positive control: corresponds to the genotype infested with $D$. opuntiae; Negative control: corresponds to the genotype without infestation of $D$. opuntiae. Source: Authors

When the contrasts were between chemical treatments and a negative control, they were also considered for the three varieties (Table 2). The contrast between the biological treatments with the negative control as well as the chemical treatments with the negative control for the variety $O$. ficus indica has not been calculated, and for $O$. atropes and $O$. stricta, the control had significance with greater activity.

When it comes to drawing a profile of biochemical responses from cochineal infested palm and the use of fungi as biocontrol, there are gaps, since previous work is still incipient. Silva et al. (2017) evaluated the antagonistic potential Trichoderma spp. against plant pathogens also showed such chemical gaps. The same authors in an experiment testing $T$. harzianum had increased PAL activity in cassava plants infected with Scytalidium lignicola.

Phenylalanine ammonia lyase is considered an important marker of resistance induction in secondary plant metabolism (Almeida et al., 2012). This enzyme is the first in the phenylpropanoid pathway to eliminate ammonia from Lphenylalanine and produce trans-cinnamic acid. This acid is used in the biosynthesis of phenylpropanoid compounds such as flavonoids and lignin (Rahmatabadi et al., 2019). Lignin acts directly on the preservation of the cell wall, providing mechanical 
support against damage caused by herbivory, also providing resistance to abiotic stresses (Tarazi et al., 2020). And flavonoids have the ability to scavenge free radicals and chelate metal ions, other functions include preventing fatty acid oxidation, protection against free radicals and lipid peroxidation, and in the supply of hydrogen (Silva et al., 2015).

In the first collection that occurred on the $15^{\text {th }}$ day after infestation, plants of the $O$. atropes genotype submitted to the treatments of Trichoderma spp. as well as chitosan, they obtained results from similar negative testimony activities, being statistically equal. While for $O$. ficus indica, the negative control showed the highest average and was the collection with the most expressive activity, being statistically equal for the three varieties, $O$. stricta, treatment with $T$. viride URM 6823 was the one with the highest overall average with $23.541 \mu \mathrm{mol} \mathrm{mg} \mathrm{m}^{-1}$ prot. $\mathrm{min}^{-1}$ (Table 3).

In the second analysis of the PAL, at 45 days, the treatments applied to $O$. atropes did not differ statistically from each other and the same result was reflected in the third following collection. While for $O$. ficus it indicates the controls as well as the plants treated with A. pullulans URM 6874 did not differ and were inferior to the other treatments. In the $O$. stricta genotype, the treatments $T$. viride URM 6823 and the control without scale insects $\left(13.666\right.$ and $\left.15.791 \mu \mathrm{mol} \mathrm{mg}^{-1} \mathrm{prot}^{\mathrm{min}}{ }^{-1}\right)$ obtained, respectively, the highest averages and were statistically equal, the results of the other treatments did not differ each other. Brandão (2020) evaluated the activity of PAL in palm plants of the species Nopalea cochenilifera and Opuntia tuna in young cladodes grown in open field conditions, found that the activity in the cladodes shortly after pruning was greater.

The activity of this enzyme causes defense of the plant against infections and as the severity increases there is also an increase in its action (Spolti et al., 2015), as shown in table 3. The significant increases in PAL in the susceptible variety can be attributed to induced defense, the same effect was noticed by Stadnik and Buchenauer (2000) in wheat plants inoculated with Blumeria graminis and treated with acibenzolar-S-methyl. Spolti et al. (2015) still exposes in his research with apple rot known as "bull's eye" (Cryptosporiopsis perennans) that a higher content of PAL and PPO were found in samples with phosphate inducer of potassium than only treated with water. In the experimental conditions imposed on the palm genotypes, there was a low variation in the treatment (negative control).

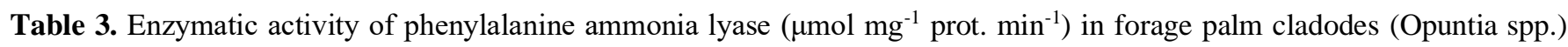
artificially infested with Dactylopius opuntiae, after application of resistance inducers, in the three collection periods.

\begin{tabular}{|c|c|c|c|c|c|c|c|c|}
\hline \multicolumn{9}{|c|}{ Collection 1} \\
\hline & TRIC 24 & TRIC 23 & AUR & CHIT & $\mathbf{S A}$ & ABA & CWM & CWMB \\
\hline Tolerant & $13.207 \mathrm{Aa}$ & $12.342 \mathrm{Ab}$ & $6.517 \mathrm{Ba}$ & $10.883 \mathrm{Aa}$ & $3.930 \mathrm{Ba}^{\mathrm{c}}$ & $6.707 \mathrm{Ba}$ & $6.087 \mathrm{Ba}$ & $14.281 \mathrm{Aa}$ \\
\hline Susceptible & $7.096 \mathrm{Bb}^{\mathrm{b}}$ & $7.531 \mathrm{Bb}^{\mathrm{b}}$ & $3.277 \mathrm{Ca}^{\mathrm{c}}$ & $2.718 \mathrm{Cb}^{\mathrm{b}}$ & $5.369 \mathrm{Ca}^{\mathrm{b}}$ & $3.855 \mathrm{Ca}^{\mathrm{c}}$ & $3.402 \mathrm{Ca}^{\mathrm{b}}$ & $12.207 \mathrm{Aa}$ \\
\hline Resistant & $8.166 \mathrm{Cb}$ & $23.541 \mathrm{Aa}^{\mathrm{a}}$ & $8.115 \mathrm{Ca}$ & $11.976 \mathrm{Ba}$ & $6.726 \mathrm{Ca}$ & $4.966 \mathrm{Ca}^{\mathrm{c}}$ & $4.606 \mathrm{Ca}^{\mathrm{b}}$ & $12.377 \mathrm{Ba}$ \\
\hline \multicolumn{9}{|c|}{ Collection 2} \\
\hline Tolerant & $10.379 \mathrm{Ab}$ & $11.110 \mathrm{Aa}$ & 9.277Aa & 8.388Ab & $11.624 \mathrm{Aa}^{\mathrm{a}}$ & $11.549 \mathrm{Aa}$ & 8.439Aa & $12.545 \mathrm{Aa}$ \\
\hline Susceptible & $16.258 \mathrm{Aa}^{\mathrm{a}}$ & $11.416 \mathrm{Ba}^{\mathrm{b}}$ & $9.499 \mathrm{Aa}^{\mathrm{b}}$ & $15.527 \mathrm{Aa}^{\mathrm{a}}$ & $13.990 \mathrm{Aa}^{\mathrm{a}}$ & $14.689 \mathrm{Aa}^{\mathrm{b}}$ & $10.666 \mathrm{Ba}^{\mathrm{a}}$ & $10.050 \mathrm{Ba}$ \\
\hline Resistant & $6.791 \mathrm{Bb}$ & $13.666 \mathrm{Aa}^{\mathrm{b}}$ & $9.068 \mathrm{Ba}$ & $8.893 \mathrm{Bb}$ & $8.476 \mathrm{Ba}$ & $8.804 \mathrm{Ba}^{\mathrm{b}}$ & $5.768 \mathrm{Ba}^{\mathrm{b}}$ & $15.791 \mathrm{Aa}$ \\
\hline \multicolumn{9}{|c|}{ Collection 3} \\
\hline Tolerant & $8.869 \mathrm{Ab}$ & $11.698 \mathrm{Ab}$ & $6.475 \mathrm{Ab}$ & $9.013 \mathrm{Aa}$ & $9.337 \mathrm{Ab}^{\mathrm{b}}$ & 7.119Ac & 6.342Aa & $9.865 \mathrm{Ab}$ \\
\hline Susceptible & $21.152 \mathrm{Aa}^{\mathrm{a}}$ & $20.513 \mathrm{Aa}^{\mathrm{a}}$ & $15.619 \mathrm{Ba}^{\mathrm{a}}$ & $11.934 \mathrm{Ca}^{\mathrm{a}}$ & $15.559 \mathrm{Ba}^{\mathrm{a}}$ & $22.971 \mathrm{Aa}^{\mathrm{a}}$ & $9.189 \mathrm{Ca}^{\mathrm{a}}$ & $10.050 \mathrm{Cb}$ \\
\hline Resistant & $12.342 \mathrm{Ab}$ & $14.726 \mathrm{Ab}^{\mathrm{b}}$ & $11.272 \mathrm{Aa}$ & $10.061 \mathrm{Aa}$ & $9.694 \mathrm{Ab}$ & $13.133 \mathrm{Ab}^{\mathrm{a}}$ & $10.610 \mathrm{Aa}^{\mathrm{a}}$ & $15.791 \mathrm{Aa}$ \\
\hline
\end{tabular}

Capital letters on the line compare the palm with the different treatments within the collection. Lower case letters in the column compare the treatment within each genotype of palms to each other in that collection. Exponential letters compare the genotype within the treatment by 
collections. Similar letters do not differ by the Scott-Knott test at 5\%. T. viride URM 6824 (TRIC 24), T. viride URM 6823 (TRIC 23), Aureobasidium pullulans URM 6874 (AUR), Chitosan (CHIT); Salicylic acid (SA); Aminobutyric acid (ABA); Control with mealybug (CWM); Control without mealybug (CWMB). Source: Authors.

In the third collection, in the genotype $O$. ficus indicates treatments with biotic and abiotic inducers differed from controls with superior enzymatic activities, among such results the plants treated with T. viride URM 6824, T. viride URM 6823 and ABA showed higher averages. In vegetables PAL plays a major role in the mechanisms of defense, growth and development, being present at the branching point of the primary to the secondary metabolism and acts as a link between the two. It is also involved in the production of bioactive compounds, being studied as a biochemical marker for the effectiveness of alternative controls and biocontrol, due to the positive correlation with increased activity (Habibollahi et al., 2020).

\section{Conclusions}

The attack of the pest causes serious damage to the plant, directly impacting the production, requiring efficient control measures in management. The fungi Trichoderma spp. and aminobutyric acid (ABA) provide greater enzyme activity of phenylalanine ammonia lyase in the genotype IPA 100003 O. ficus indica. Such an enzyme is a precursor for the formation of phenolic groups essential for the cellular structure of the plant. When analysing orthogonal contracts, biological and chemical treatments showed significant results in the three genotypes studied. Future research will be necessary in field conditions to verify the potential use of the inductors analyzed in the genotypes.

\section{References}

Almeida, H. O. et al. (2012). Enzimas marcadoras de indução de resistência diferencialmente reguladas em soja resistente e suscetível à ferrugem-asiática-da-soja. Pesquisa Agropecuária Brasileira, 47 (2), 163-172.

Canuto, C. et al. (2019). Biochar e esterco bovino aumentam a eficiência no uso de água da alface. Diversitas Journal, 4 (3), $1082-1091$.

Carvalho, C. B. M. et al. (2018). Uso de cactáceas na alimentação animal e seu armazenamento após colheita. Archivos de Zootecnia, 67 (259), $440-446$.

Dubeux Jr, J. C. B. et al. (2015). Forage potential of cacti on drylands. Acta Horticulturae, 1 (1067), 181-186.

Ferraz, A.P.F. et al. (2017). Incidence of cochineal insects in cactus pear genotypes in the seminarid region of Pernambuco. IX International Congress on Cactus Pear and Cochineal: CAM crops for a hotter and drier world, Proceedings. p.143.

Habibollahi, M. et al. (2020). Cloning, characterization and expression of a phenylalanine ammonia-lyase gene (CcPAL) from cumin (Cuminum cyminum L.). Journal of Applied Research on Medicinal and Aromatic Plants, 18, 100253.

INMET (2020). Instituto Nacional de Meteorologia. Bancos de dados meteorológicos do INMET.

Luna, J. A. P. et al. (2018). Ciclo de vida y fecundidad de Dactylopius opuntiae (Hemiptera: Dactylopiidae) en Opuntia ficus-indica (Caryophyllales: Cactaceae). Agrociencia, 52, 103-114.

Melo, L. G. L. et al. (2016). Indutores de resistência abióticos no controle da fusariose do abacaxi. Pesquisa Agropecuária Brasileira, 51 (10), $1703-1709$.

Pascholati, S. F., Souza, V. H. M., Cardoso Filho, J. A (2019). Indução de resistência por Trichoderma. In: Trichoderma: uso na agricultura. Meyer, M. C. Brasília, DF: Embrapa. 538 p. 235-254.

Peixoto, M. J. A. et al. (2018). Características agronômicas e composição química da palma forrageira em função de diferentes sistemas de plantio. Archivos de Zootecnia, 67 (257) 35-39.

Rahmatabadi, S. et al. (2019). Identification and characterization of a sterically robust phenylalanine ammonia-lyase among 481 natural isoforms through association of in silico and in vitro studies. Enzyme and Microbial Technology, 122, 36-54.

Silva, J. A. T. et al. (2017). Antagonistic activity of Trichoderma spp. against Scytalidium lignicola CMM 1098 and antioxidant enzymatic activity in cassava. Phytoparasitica, 45, 219-225.

Silva, J. M. et al. (2018). Resistance inducers and biochemical mechanisms in the control of anthracnose in cowpea. Ciencia e Investigación Agraria, 45 (3), 290-300.

Silva, T. G. F. et al. (2015). Crescimento e produtividade de clones de palma forrageira no semiárido e relações com variáveis meteorológicas. Revista Caatinga, 28 (2) 10-18. 
Research, Society and Development, v. 10, n. 5, e41610515106, 2021

(CC BY 4.0) | ISSN 2525-3409 | DOI: http://dx.doi.org/10.33448/rsd-v10i5.15106

Sousa, S. G (2019) Análise temporal do comportamento da precipitação pluviométrica na Região Metropolitana do Cariri (CE), Brasil. Revista Geográfica da América Central, 2 (63), 319-340.

Spolti, P. et al. (2015). Modo de ação de fosfitos de potássio no controle da podridão olho de boi em maçã. Summa Phytopathologica, 41 (1), $42-48$.

Stadnik, M. J.; Buchenauer, H. (2000). Inhibition of phenylalanine ammonia-lyase suppresses the resistance induced by benzothiadiazole in wheat to Blumeria graminis f. sp. tritici. Physiological and Molecular Plant Pathology, 57 (1), 25-34.

Tarazi, R. et al (2019). Biotechnological solutions for major cotton (Gossypium hirsutum) pathogens and pests. Biotechnology Research and Innovation, 3 (1), $19-26$.

Wang, W. et al (2020). Induction of defense in cereals by 4-fluorophenoxyacetic acid suppresses insect pest populations and increases crop yields in the field. Proceedings of the National Academy of Sciences of the United States of America, 117 (22), 12017-12028.

Zucker, M (1968). Sequential induction of phenylalanine ammonia-lyase and a lyase-inactivating system in potato tuber disks. Plant Physiology, 43 (2), 365374. 